\section{MOVE FOR ACTION ON HEA}

Adjournment fever is developing among the nation's lawmakers and the current speculations reflect a variety of educated guesses as to when Congress will decide to end this session and go home. This uncertainty is of major concern to librarians, particularly to ACRL members, because the Higher Education Act of 1965 -PL 89-329-requires renewed authorizations if programs are to be funded beyond June 30 , 1968, when the present legislation expires. Legislation for the extension of HEA was introduced early in the 90th Congress-Higher Education Amendments of 1967 (H.R. 6232 and S. 1126and hearings were conducted by the House Special Education Subcommittee, chaired by Rep. Edith Green (D-Ore.). In early June, the Subcommittee began closed executive sessions and it was expected that a bill would be ready for a House vote by summer's end, with Senate action coming shortly thereafter.

Due to a series of complications involving other legislation, the House Committee has not yet reported out this bill and the Senate has not begun Committee consideration. But there is still every expectation that both bodies will take action on the measure early in the second session.

What to Do: In the meantime while Members are home for the holidays college librarians should make every effort to get their presidents to talk to their Senators and Congressmen. Arm your spokesman with all the pertinent facts regarding the institutions' library needs in terms of students' services. Impress him with the urgency for early action on this vital measure to aid institutions of higher education. Librarians and college administrators alike will be unable to do any advance planning and another eleventh-hour cliff-hanging situation will develop if Congress does not act immediately when the second session is convened in January.

For Senators, urge action on S1126

For Representatives, urge action on HR6232

\section{ACRL Membership}

October 31, 1967

October 31, 1966

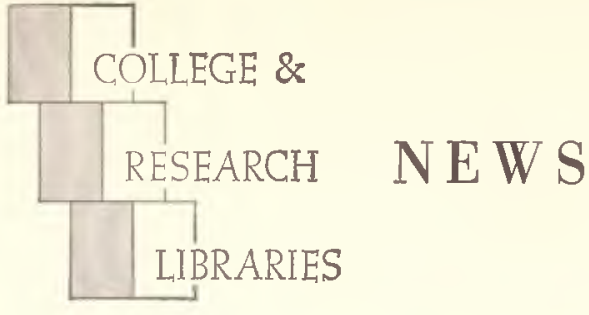

ACRL News Issue of College \& Research Libraries

Editor, David Kaser, Joint University Libraries, Nashville, Tenn. 37203.

Publications Officer, Mary Falvey, 50 E Huron St., Chicago 60611.

ACRL Executive Secretary, George M. Bailey

ACRL Officers, 1967/68: President, James Humphry III; College Libraries Section Chairman, Audrey North; Junior College Libraries Section, Mrs. Alice B. Griffith; Rare Books Section, Lawrence S. Thompson; Subject Specialists Section, Richard L. Snyder; Agriculture and Biological Sciences Subsection, Mrs. Pauline W. Jennings; Art Subsection, James K. Dickson; Law and Political Science Subsection, Morris Cohen; Slavic and East European Subsection, Jerzy (George) J. Maciuszko; University Libraries Section, Stuart Forth.

Editorial Board: John M. Dawson, University of Delaware; Gustave A. Harren, Boston University; SAMtuel RothsteIN, University of British Columbia; James E. Skipper, Princeton University; Norman E. Tanis, Kansas State College of Pittsburg; Maunice F. TAuber, Columbia University; EIIEen Thornton, Oberlin College.

News from the Field, Personnel profiles and notes, classified advertising official matter of ACRL, and other material of a timely nature is published in the News issues of College \& Research Libraries.

Inclusion of an article or advertisement in CRL does not constitute official endorsement by ACRL or ALA.

Production and Advertising and Circulation office: 50 E. Huron St., Chicago, III. 60611. Change of address and orders for subscriptions should be addressed to College of Research Libraries, for receipt at the above address, at least two months before the publication date of the effective issue.

Subscription to CRL is included in membership dues to $A C R L$ of $\$ 6$ or more; other subscriptions to $C R L$ are $\$ 10$ per year. Neither subscriptions nor memberships include miscellaneous unscheduled supplements, which are available by purchase only. Retroactive subscriptions are not accepted. Single journal copies are available at $\$ 1.50$ each and News issues at $\$ 1.00$ each from ALA Publishing Department.

Indexed in Library Literature. Abstracted in Library Science Abstracts. Book reviews indexed in Book Review Index.

College \& Research Libraries, is the official joumal of the Association of College and Research Libraries, a division of the American Library Association; and is published seventeen times per year-bi-monthly as a fechnical journal with 11 monthly News issues, combining July-August-at 1201-05 Bluff St., Fulton, Mo. 65251 .

Second-class postage paid at Fulton, Mo. and at additional mailing offices. 